\title{
Penggunaan Media Laboratorium Virtual PhET Simulation untuk Meningkatkan Pemahaman Konsep Fisika Mahasiswa pada Mata Kuliah Eksperimen Fisika Sekolah
}

\author{
Yoan Theasy ${ }^{1, *)}$, Andi Bustan ${ }^{2}$, M. Nawir ${ }^{3}$ \\ Program Studi Pendidikan Fisika, Fakultas Keguruan dan Ilmu Pendidikan \\ Universitas Palangka Raya, Indonesia \\ yoante321@gmail.com ${ }^{1}$, abustan@fkip.upr.ac.id ${ }^{2}$, nawir0393@gmail.com ${ }^{3}$ \\ ${ }^{*}$ Corresponding author
}

\section{Kata Kunci: \\ Laboratorium Virtual; PhET \\ Simulation; Pemahaman \\ Konsep}

\begin{abstract}
ABSTRAK
Pelaksanaan pembelajaran di masa pandemi Covid-19 memiliki banyak keterbatasan, antara lain adalah kegiatan kuliah tatap muka serta kegiatan praktikum di laboratorium yang dialihkan ke sistem pembelajaran dalam jaringan. Hal ini mengakibatkan antara lain kemampuan pemahaman konsep mahasiswa dalam pembelajaran fisika menjadi menurun. Tujuan penelitian ini adalah memanfaatkan laboratorium virtual Physic Education and Technology (PhET) simulation sebagai media pembelajaran di masa pandemi Covid-19 sebagai salah satu solusi yang dapat dilakukan dalam upaya untuk meningkatkan pemahaman konsep fisika mahasiswa. Jenis penelitian ini merupakan penelitian kuantitatif. Penelitian ini dilakukan dengan metode eksperimen berbentuk one group pretest-posttest design. Sampel penelitian yaitu mahasiswa Program studi Pendidikan Fisika Tahun Ajaran 2020/2021 sebanyak 26 orang ditentukan dengan teknik purposive sampling. Penelitian ini menggunakan satu kelas untuk diteliti yang diberi perlakuan dengan memanfaatkan laboratorium virtual Physic Education and Technology (PhET) simulation sebagai media pembelajaran. Instrumen yang digunakan dalam penelitian ini adalah soal pemahaman konsep dalam bentuk tes uraian. Pengambilan data dilakukan dua kali yaitu sebelum melakukan treatment (pretest) dan sesudah melakukan treatment (posttest), kemudian untuk mengetahui peningkatan pemahaman konsep fisika mahasiswa dilakukan uji N-gain. Hasil analisis data menunjukkan bahwa peningkatan hasil belajar mahasiswa memperoleh kriteria tinggi dengan skor $\mathrm{N}$ gain sebesar 0,732. Oleh karena itu hasil studi menyatakan bahwa penggunaan laboratorium virtual PhET simulation sebagai media pembelajaran dapat meningkatkan kemampuan pemahaman konsep fisika mahasiswa.
\end{abstract}




\section{PENDAHULUAN}

Masa pandemi Covid-19 sangat mempengaruhi kegiatan belajar mengajar di sekolah maupun Universitas. Proses pembelajaran tatap muka serta kegiatan praktikum di laboratorium tidak dapat terlaksana sebagaimana mestinya. Menurut Yahya, Hermansyah, dan Fitrianto (2019) menyatakan bahwa eksperimen dalam pembelajaran IPA khususnya fisika bermanfaat untuk mengkonstruk pemahaman siswa dalam memahami gejala alam, konsep, dan prinsip sains. Kegiatan ini sangat penting dilakukan oleh siswa untuk membuktikan konsep-konsep dari teori-teori yang telah dipelajari. Fisika pada hakekatnya melibatkan dimensi produk berupa kumpulan teori yang telah teruji kebenarannya dan dimensi produk berupa serangkaian kegiatan yang harus dilakukan untuk memperoleh pengetahuan dan gejala-gejala alam yang kita kenal sebagai metode ilmiah.

Menurut Tuhusula et al. (2020), pada dasarnya kegiatan eksperimen di dalam laboratorium harus dilaksanakan dalam pembelajaran fisika yang mana membutuhkan ruang laboratorium. Sebagai alternatif virtual laboratorium dapat digunakan. Masa Pandemi Covid-19 membuat kegiatan pembelajaran tatap muka serta kegiatan praktikum di laboratorium tidak dapat terlaksana sebagaimana mestinya, sehingga mempengaruhi menurunnya kemampuan pemahaman konsep serta keterampilan mahasiswa dalam pembelajaran fisika. Hal ini terlihat dari hasil belajar fisika mahasiswa pada mata kuliah Eksperimen Fisika Sekolah. Data hasil tes mahasiswa S-1 program studi pendidikan fisika Universitas Palangka Raya (UPR) pada semester VI pada mata kuliah Eksperimen Fisika Sekolah tahun akademik 2019/2020 menunjukkan 20 orang dari 36 mahasiswa mendapatkan rentang nilai 5060 (skala maksimal 100). Setelah dilakukan wawancara langsung dengan beberapa mahasiswa secara online, maka diketahui bahwa pemahaman konsep mahasiswa tentang materi pembelajaran fisika masih kurang. Penyebab hal tersebut adalah mahasiswa masih kurang memahami konsep materi fisika, sehingga pada saat diberikan suatu soal mengenai konsep fisika mereka akan mengalami kebingungan dalam menyelesaikan soal tersebut. Mahasiswa terbiasa untuk menyelesaikan soal dalam bentuk perhitungan, dan masih kurang dalam penguasaan konsep. Pemahaman konsep adalah proses perbuatan untuk mengerti benar tentang suatu rancangan atau suatu ide abstrak yang memungkinkan seseorang untuk menggolongkan suatu objek atau kejadian, dan pemahaman konsep diperoleh melalui proses belajar (Henny, 2012).

Pemahaman merupakan hasil belajar mengajar yang mempunyai indikator dan setiap individu dapat menjelaskan atau mendefinisikan suatu bagian informasi dengan kata-kata sendiri. Dosen sebagai pengajar sudah semestinya selalu berusaha untuk membuat peserta didik tetap aktif dan maksimal dalam belajar meskipun hanya dari rumah, yaitu salah satunya dengan belajar dalam jaringan (daring) dengan pemberian materi melalui aplikasi belajar seperti google classroom dan zoom. Tetapi hal tersebut tidaklah cukup karena diperlukan suatu pembelajaran yang tidak hanya mampu menguasai konsep saja tetapi juga mampu menyesuaikannya dengan praktik. Eksperimen yang seharusnya dilakukan di laboratorium sebagai tempat untuk mengaplikasikan teori keilmuan, pengujian teoritis, pembuktian uji coba, penelitian dan sebagainya dengan menggunakan alat bantu yang menjadi kelengkapan dari fasilitas dengan kuantitas dan kualitas yang memadai tidak dapat terlaksana seperti biasanya diakibatkan karena masa pandemi Covid-19. Yatin, Hadma, dan Luvia (2020) menyatakan bahwa penggunaan media belajar pada pembelajaran fisika berbasis daring selama pandemi Covid-19 memiliki tantangan tersendiri terutama kegiatan praktikum. Pada pembelajaran praktikum, media belajar yang ditemukan masih minim dan terbatas pada alat praktikum yang digunakan secara langsung. Padahal pembelajaran ini mengharuskan adanya media belajar baru, aktif, dan konstruktif yang mendukung proses pembelajaran jarak jauh. Oleh sebab itu, diperlukan praktikum virtual untuk memenuhi tuntutan tersebut. Salah satu upaya untuk mengatasi masalah tersebut adalah dengan pemanfaatan teknologi dan informasi dan komputer. 
Kemajuan ilmu pengetahuan, teknologi, komunikasi dan informasi sangat membantu dalam menghasilkan media pembelajaran. Berbagai media interaktif telah diproduksi dan diaplikasikan oleh banyak sekolah dan lembaga pendidikan. Begitu pula halnya kegiatan percobaan sudah dapat digantikan melalui media simulasi interaktif. Melalui media simulasi interaktif ini, kegiatan percobaan dapat dikerjakan oleh siswa (Sinulingga et al., 2016). Teknologi komputer dapat digunakan untuk menunjang pelaksanaan praktikum fisika, baik untuk memahami konsep, mengumpulkan data, maupun menyajikan dan mengolah data. Selain itu, komputer juga dapat digunakan untuk memodifikasi eksperimen dan menampilkan eksperimen lengkap dalam bentuk virtual yang disebut Virtual Laboratory Model (VLM). Peserta didik dapat melakukan kegiatan eksperimen dengan menggunakan laboratorium virtual. Laboratorium virtual atau yang sering juga disebut sebagai simulasi virtual adalah suatu bentuk laboratorium dengan kegiatan pengamatan atau eksperimen dengan menggunakan software yang dijalankan pada sebuah computer (Saputra, Nur, \& Purnomo, 2017).

Laboratorium virtual memiliki kelebihan, yaitu dapat digunakan untuk menjelaskan konsep abstrak yang tidak dapat dijelaskan secara verbal. Penggunaan laboratorium virtual juga tidak memerlukan persiapan yang lama karena pengajar tidak perlu mempersiapkan alat dan bahan yang diperlukan dalam percobaan. Salah satu laboratorium virtual yang banyak dimanfaatkan dalam bidang pendidikan dan penelitian adalah simulasi PhET (Physics Education Technology) yang diciptakan oleh komunitas sains melalui PhET Project di University of Colorado, USA. Simulasi ini bersifat interaktif yang dapat diunduh secara gratis dan dapat diakses secara online maupun offline (Supurwoko et al., 2017). Penelitian yang dilakukan oleh Sugiana et al. (2016) menyatakan bahwa terdapat pengaruh positif terhadap penguasaan konsep dan kreativitas siswa kelompok eksperimen fisika yang diperlakukan menggunakan model pembelajaran berbasis generatif menggunakan media laboratorium virtual. Pernyataan tersebut didukung oleh penelitian yang sudah dilakukan oleh Siti et al. (2020) mengenai Penggunaan PhET Simulation dalam meningkatan pemahaman konsep fisika peserta didik, dimana hasil penelitian menunjukkan peningkatan pemahaman konsep fisika pada kelas eksperimen sebesar 0,62 sedangkan untuk kelas kontrol sebesar 0,13. Berdasarkan hasil perhitungan $N$-gain dapat dikatakan bahwa pembelajaran dengan menggunakan PhET Simulation dapat meningkatkan pemahaman konsep fisika peserta didik. Kemudian hasil penelitian yang telah dilakukan oleh Suhandi (2009) bahwa penggunaan media simulasi PhET lebih banyak menurunkan miskonsepsi pada peserta didik jika dibandingkan menggunakan alat peraga pada materi rangkaian listrik. Hal tersebut dikarenakan karakteristik simulasi PhET dapat menyajikan fenomena yang sifatnya mikroskopis dan abstrak ke dalam bentuk nyata dbandingkan menggunakan alat peraga. Selanjutnya penelitian yang sudah dilakukan oleh Dedi, Wahab, dan Jamal (2020) menyatakan bahwa (1) media simulasi PhET secara efektif digunakan untuk membantu guru dan siswa dalam mempelajari konsep Fisika, (2) sangat baik dikombinasikan dengan pembelajaran inkuiri, serta (3) efektif dalam menjelaskan konsep Fisika yang sifatnya abstrak. Berdasarkan uraian diatas, penelitian ini bertujuan untuk memanfaatkan laboratorium virtual Physic Education and Technology (PhET) simulation sebagai media pembelajaran di masa pandemi Covid-19 untuk meningkatkan pemahaman konsep fisika mahasiswa pada mata kuliah eksperimen fisika sekolah.

\section{METODE PENELITIAN}

Jenis penelitian ini adalah penelitian kuantitatif. Penelitian ini dilakukan dengan metode eksperimen berbentuk one group pretest-posttest design. Penggunaan desain ini dipilih karena hendak memperoleh data mengenai peningkatan kemampuan suatu sampel penelitian setelah dilakukan perlakuan terhadap sampel tersebut. Penelitian ini dilaksanakan di Universitas Palangkaraya. Sampel penelitian adalah mahasiswa Program studi Pendidikan Fisika Tahun Ajaran 2020/2021 sebanyak 26 orang ditentukan dengan teknik purposive sampling. Pengumpulan data dilakukan dengan pemberian soal tes kemampuan pemahaman konsep mahasiswa untuk melihat peningkatan pemahaman konsep mahasiswa. Instrumen yang digunakan dalam penelitian ini adalah tes kemampuan pemahaman konsep yang telah divalidasi sebelumnya oleh beberapa ahli. Menurut Arikunto (2010: 203), "Instrumen adalah alat atau fasilitas yang digunakan dalam mengumpulkan data agar pekerjaannya 
lebih mudah dan hasilnya lebih baik, dalam arti lebih cermat, lengkap dan sistematis sehingga lebih mudah diolah". Penelitian ini berusaha untuk mendeskripsikan bagaimana pemanfaatan laboratorium virtual PhET Simulation sebagai media pembelajaran dalam upaya meningkatkan pemahaman konsep fisika mahasiswa.

Pada tahap pelaksanaan penelitian ini terdiri dari beberapa tahap yang dilakukan. Pada tahap pelaksanaan ini diberi perlakuan dengan memanfaatkan laboratorium virtual Physic Education and Technology (PhET) simulation sebagai media pembelajaran. Pengambilan data dilakukan dua kali yaitu sebelum melakukan treatment (pretest) dan sesudah melakukan treatment (posttest) untuk melihat peningkatan pemahaman konsep fisika mahasiswa. Selain itu, mahasiswa juga diajarkan cara menggunakan simulasi yang terdapat pada $\mathrm{PhET}$, kemudian mahasiswa melakukan sebuah eksperimen pengambilan data menggunakan Media Laboratorium Virtual PhET Simulation yang selanjutnya dilaporkan dalam bentuk laporan penelitian. Data hasil penelitian ini diperoleh dari hasil nilai pretest dan posttest yang dianalisis menggunakan uji $N$-gain. Pada analisis uji $N$-gain terdapat beberapa kategori peningkatan, kategori tersebut dapat dilihat pada Tabel 1.

Tabel 1. Kriteria Indeks Rerata Gain Dinormalisasi

\begin{tabular}{ll}
\hline Kriteria Perolehan $\langle g\rangle$ & Interpretasi \\
\hline $0,70<\langle g\rangle \leq 1,00$ & Tinggi \\
$0,30 \leq\langle g\rangle \leq 0,70$ & Sedang \\
$0,00<\langle g\rangle\langle 0,30$ & Rendah \\
$\langle g\rangle=0,00$ & Tidak terjadi peningkatan \\
$-1,00 \leq\langle g\rangle\langle 0,00$ & Terjadi penurunan \\
\hline
\end{tabular}

\section{HASIL DAN PEMBAHASAN}

Rekapitulasi hasil pretest, posttest dan gain yang dinormalisasi ( $N$-gain) peningkatan pemahaman konsep mahasiswa untuk materi getaran harmonik disajikan pada Tabel 2.

Tabel 2. Hasil $N$-gain Tes Pemahaman Konsep Mahasiswa

\begin{tabular}{lllll}
\hline Pretest & Posttest & $\boldsymbol{N}$-gain & $\mathbf{\%} \boldsymbol{N}$-gain & Kategori \\
\hline 61,5 & 89,7 & 0,732 & 73,2 & Tinggi \\
\hline
\end{tabular}

Berdasarkan Tabel 2, terlihat bahwa perolehan skor $\mathrm{N}$-gain sebesar 0,732 atau 73,2 \%, dengan skor gain yang dinormalisasi kriteria yaitu $0,70 \leq\langle g\rangle \leq 1,00$ kategori tinggi. Hal ini memperlihatkan bahwa terdapat peningkatan pemahaman konsep fisika yang sangat baik. Rincian nilai pretest mahasiswa sebesar 61,5 dan setelah menggunakan media pembelajaran PhET Simulation sebagai laboratorium virtual pada materi getaran harmonik, diperoleh nilai posttest 89,7 yang menggambarkan bahwa terjadi pengaruh yang positif dan peningkatan yang baik pula terhadap pemahaman konsep fisika mahasiswa. Pada pembelajaran dengan menggunakan PhET simulation sebagai laboratorium virtual, mahasiswa diarahkan untuk melakukan praktikum mengenai topik getaran harmonik. PhET simulation dapat diakses secara online maupun offline, sehingga dapat mempermudah mahasiswa untuk melakukan pembelajaran dimana saja. Pada program PhET terdapat 2 simulasi yang termasuk kedalam topik getaran harmonik, yaitu Masses and spring dan Pendulum Lab. Mahasiswa dibentuk dalam beberapa kelompok, kemudian diberikan LKPD sesuai dengan tema masing-masing simulasi tersebut. Setelah itu, tiap kelompok diharuskan untuk membuat hasil laporan berdasarkan hasil praktikum yang sudah dilakukan. Menurut Prihatiningtyas, Prastowo, dan Jarmiko (2013), simulasi PhET memberikan kesan yang positif , menarik, dan menghibur serta membantu penjelasan secara mendalam tentang suatu fenomena alam. Sejalan dengan hal tersebut, Permata dan Mariati (2016) dalam penelitiannya mengenai pengaruh model Discovery Learning berbantuan media PhET terhadap hasil belajar siswa, diperoleh kesimpulan rata-rata persentase perkembangan aktivitas, sikap dan keterampilan masing-masing dalam kategori baik sedangkan di kelas kontrol rata-rata persentase perkembangan sikap termasuk dalam kategori cukup baik. Pembelajaran seperti ini diharapkan dapat 
meningkatkan kemampuan pemahaman konsep mahasiswa dengan menghubungkan antara teori yang diajarkan dan praktik yang dilakukan.

\section{A. Percobaan 1}

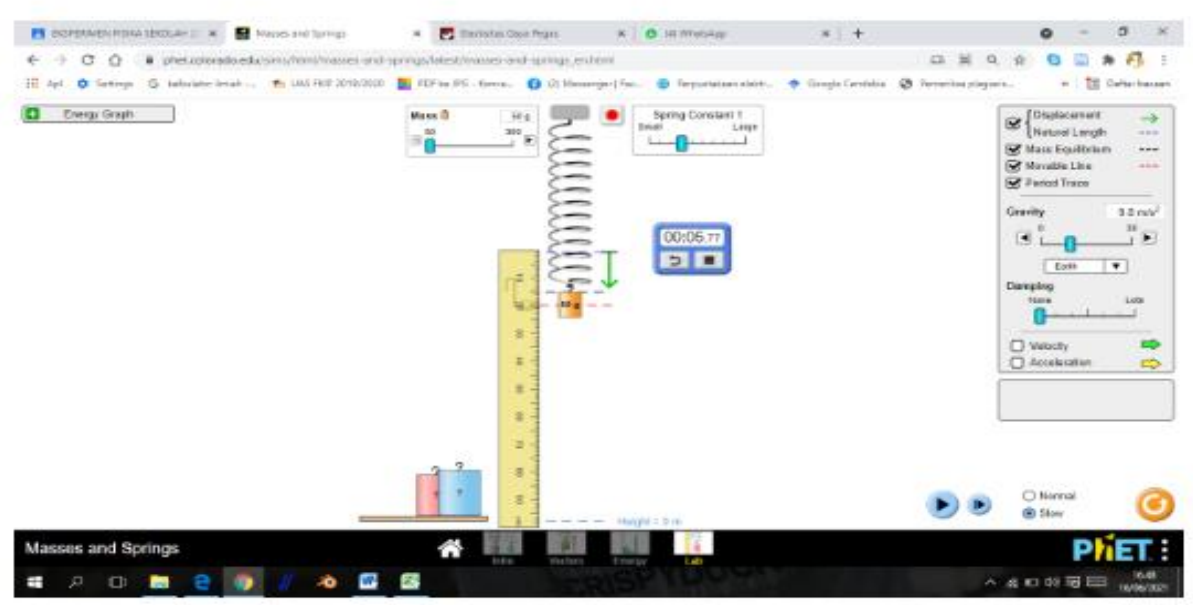

Gambar 1. Simulasi Masses and Spring (Hubungan antara Massa Beban terhadap Periode Getaran Harmonik pada Pegas).

Sumber: http://phet.colorado.edu/en/about. [04 Juni 2021]

6. Centang semua value lalu tarik bandul hingga membentuk sudut $15^{\circ}$ dengan panjang tali $0,50 \mathrm{~m}$ dan massa beban $1 \mathrm{~kg}$

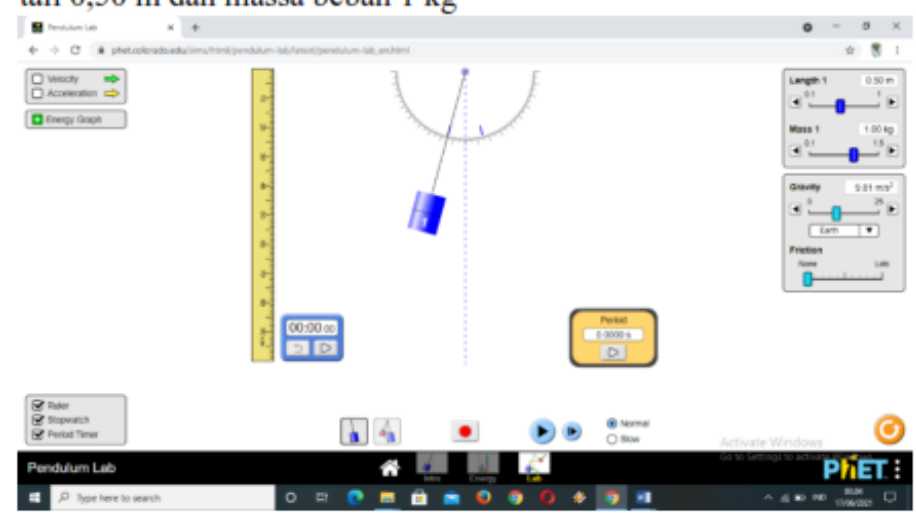

Gambar 2. Simulasi Pendulum Lab (Hubungan antara Panjang Tali terhadap Periode dan Frekuensi Getaran pada Bandul).

Sumber: http://phet.colorado.edu/en/about. [04 Juni 2021]

Gambar 1 adalah salah satu hasil laporan praktikum materi getaran harmonik dengan tema simulasi masses and spring, dimana simulasi tersebut sudah tersedia pada program PhET yang diakses secara online oleh mahasiswa. Gambar 2 menunjukkan hasil percobaan simulasi materi getaran harmonik dengan tema pendulum lab dan juga diakses secara online oleh mahasiswa. Mahasiswa terlihat tertarik dan antusias dalam melaksanakan pembelajaran dengan menggunakan laboratorium virtual sebagai media pembelajaran. Hal ini karena selama masa pandemi covid-19, kegiatan praktikum dan eksperimen yang harusnya dilaksanakan di laboratorium nyata untuk sementara ditiadakan untuk mencegah penyebaran virus covid-19.

Pembelajaran secara mandiri menggunakan PhET simulation sebagai laboratorium virtual mampu meningkatkan pemahaman konsep pada sub materi getaran harmonik. Pembelajaran fisika hendaknya berorientasi pada keterampilan proses dengan melakukan eksperimen sehingga peserta didik memperoleh kesempatan untuk berinteraksi dengan obyek konkrit sampai dengan penemuan konsep. Selain melakukan praktikum dan eksperimen di laboratorium nyata, dapat dilakukan juga dengan 
memanfaatkan perkembangan teknologi informasi komputer (Yahya, Hermansyah, \& Fitrianto, 2019). Salah satu media pembelajaran yang penggunaannya memanfaatkan teknologi komputer, yaitu program media virtual seperti laboratorium virtual, multimedia interaktif, dan simulasi interaktif antara lain PhET simulation. Hal ini juga sejalan dengan penelitian yang telah dilakukan oleh Hikmawati, Sutrio, dan Mahesti (2019) bahwa pembelajaran fisika dengan laboratorium virtual dapat membantu peserta didik lebih mandiri, dan dapat mengembangkan kemampuan peserta didik memahami suatu konsep.

\section{KESIMPULAN}

Berdasarkan hasil penelitian dan analisis data yang telah dilakukan, maka dapat disimpulkan bahwa terdapat peningkatan pemahaman konsep fisika mahasiwa setelah memanfaatkan laboratorium virtual Physic Education and Technology (PhET) simulation sebagai media pembelajaran. Hal tersebut dapat dilihat dari hasil tes pemahaman konsep fisika mahasiswa pada materi getaran harmonik memperoleh kriteria tinggi dengan skor $N$-gain sebesar 0,732 .

\section{UCAPAN TERIMA KASIH}

Terima kasih disampaikan kepada Tim Hibah Penelitian Fakultas Keguruan dan Ilmu Pendidikan Universitas Palangka Raya Tahun Anggaran 2021, sehingga kami dapat turut berpartisipasi dalam kegiatan penelitian, kemudian terima kasih karena telah membimbing, mengarahkan dan memberikan fasilitas untuk seluruh proses penyusunan hasil penelitian sampai publikasi ilmiah. Terima kasih juga kami ucapkan kepada program studi S-1 pendidikan fisika yang telah berpartisipasi dalam kegiatan penelitian ini.

\section{DAFTAR PUSTAKA}

Arikunto. (2010). Prosedur Penelitian. Jakarta: Rineka Cipta.

Dedi, R. R., Wahab, A. J., \& Jamal. (2020). PhET: Simulasi Interaktif dalam Proses Pembelajaran Fisika. Jurnal Ilmiah Profesi Pendidikan, 5(1), 10-14.

Henny. (2012). Penerapan Pembelajaran Generatif dengan Strategi Problem Solving untuk Meningkatkan Pemahaman Konsep Siswa SMA pada Materi Fluida Statis. Skripsi. Jurusan Pendidikan FPMIPA UPI Bandung. Tidak diterbitkan. Diakses pada tanggal 5 Januari 2014.

Hikmawati., Sutrio., \& Mahesti, K. (2019). Pengenalan PhET Simulations sebagai Laboratorium Virtual. Jurnal Pendidikan dan Pengabdian Masyarakat, 2(4), 480-483.

Permata, S. D., \& Mariati, P. S. (2016). Pengaruh Model Discovery Learning Berbantuan Media PhET Terhadap Hasil Belajar Siswa. Jurnal Inpafi, 4(4), 1-9.

Prihatiningtyas, S., Prastowo., \& Jarmiko. (2013). Implementasi Simulasi PhET dan KIT Sederhana untuk Mengajarkan Keterampilan Psikomotor Siswa pada Pokok Bahasan Alat Optik. Jurnal Pendidikan IPA Indonesia, 2(1), 18-22.

Saputra, T. B. R., Nur, M., \& Purnomo, T. (2017). Pengembangan Pembelajaran Inkuiri Berbantuan PhET untuk Melatihkan Keterampilan Proses Sains Siswa. Journal of Science Education and Practice, 1(1), 20-31.

Sinulingga, P. et al. (2016). Implementasi Pembelajaran Fisika Berbantuan Media Simulasi PhET untuk Meningkatkan Hasil Belajar Siswa pada Materi Listrik Dinamis. JPPPF (Jurnal Penelitian \& Pengembangan Pendidikan Fisika), 2(1), 57-64.

Siti, I. M., Pujianti, B. D., Agustinus, A. E., \& Muhamad Epi, R. (2020). Penggunaan PhET Simulation dalam Meningkatan Pemahaman Konsep Fisika Peserta Didik. Jurnal Penelitian Pendidikan Fisika, 5(2), 136-141.

Sugiana, I. N., Ahmad, H., Hairunnisyah, S., \& Gunawan. (2016). Model Pembelajaran Generatif Berbantuan Media Laboratorium Virtual terhadap Penguasaan Konsep Fisika Siswa pada Materi Momentum dan Impuls. Jurnal Pendidikan Fisika dan Teknologi, 2(2), 61-65. 
Suhandi, A. (2009). Efektivitas Penggunaan Media Simulasi Virtual pada Pendekatan Pembelajaran Konseptual Interaktif dalam Meningkatkan Pemahaman Konsep dan Meminimalkan Miskonsepsi. Jurnal Pengajaran MIPA, 13(1), 35-47.

Supurwoko et al. (2017). Virtual Lab Experiments: Physics Education Technology (PhET) Photo Electric Effect For Senior Highs School International. Journal of Science and Applied Science: Conf Series, 2(1), 381-386.

Tuhusula, T. S. et al. (2020). Eksperimen Menggunakan Virtual Lab Berbasis PhET Simulation Dalam Pembelajaran Fisika Pada Materi Gerak Parabola. Jurnal Pendidikan Fisika, 9(2), 128-135.

Yahya, F., Hermansyah., \& Fitrianto, S. (2019). Virtual Experiment Untuk Meningkatkan Pemahaman Siswa Pada Konsep Getaran Dan Gelombang. Jurnal Pendidikan Fisika dan Teknologi, 5(1), 144-149.

Yatin, R. U., Hadma, Y., \& Luvia, R. N. (2020). Kendala Mahasiswa dalam Menggunakan Simulasi Virtual PhET pada Pembelajaran Praktikum Gelombang selama Pandemi Covid-19. Prosiding Seminar Nasional Pendidikan Fisika VI, 1-8. 